\title{
Relationship Between Foreign Direct Investments and Capital Flight in Kenya: 1998-2018
}

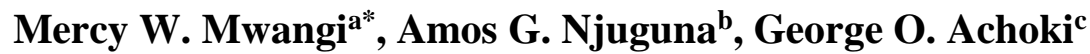 \\ United States International University, Africa \\ mercy@ihlkenya.com
}

\begin{abstract}
The study established the relationship between Foreign Direct investments and Capital Flight in Kenya over the period 1998 to 2018. Quarterly time series data for calculation of capital flight and Gross Domestic Product growth rate, inflation and Foreign Direct investments were collected from the Central Bank of Kenya and Kenya National Bureau of Statistics. Two Autoregressive Distributed-lagged model models were fitted. Regression coefficients for FDI were 0.44 and -0.040 in the short run and -0.501 in the long run. The p values were 0.008 and 0.015 and 0.654 respectively. The results indicated that a $1 \%$ increase in current quarters FDI would lead to a $0.44 \%$ increase in capital flight and a $1 \%$ increase in previous quarters FDI would lead to a decrease of $0.040 \%$ in capital flight. Regression results showed a coefficient of 0.006 and - 0.004 for Gross Domestic Product growth rate in the short run, and 0.038 in the long run. The $p$ values were 0.422, and 0.638 and 0.749 respectively meaning that Gross Domestic Product growth rate and the capital flight had no significant relationship. Regression results showed a coefficient of -0.001 and -0.005 for inflation in the short run and -0.088 for inflation for the long run. The p values were 0.844 and 0.363 and 0.253 respectively. This indicated that inflation and the capital flight had an insignificant relationship. The study recommends that government adopts strategic management on FDI inflow transactions to avoid possible leakages of the same money going out as capital flight.
\end{abstract}

\section{Article Info}

- Received : July 1, 2019

- Revised : August 15, 2019

- Published : September 15, 2019

- No. Pages : 251-267

- DOI : 10.33019/ijbe.v3i3.222

- JEL : E22, P44

- Keywords : capital flight, GDP growth rate, inflation, foreign direct investments, net inflows

\section{Introduction}

The initial occurrence of capital flight could be traced back to the 17th century in Europe and to the 20th century in USA (Wujung and Mbella, 2016). Until the early 1990s capital flight was treated entirely as a Latin America problem. Focus on capital flight on the African continent started in latter part of the 1990s (Kindleberger, 1987). Boyce and Ndikumana (2001), Ndikumana and Boyce (2003) and Collier, Hoeffler and Pattillo (2004), showed that since the 1970s, substantial amounts of funds fled from Africa as capital flight. There has been a lot of interest in researching the issue of capital flight in Africa from the early part of years 2000s (Mpenya, Metseyem and Epo, 2016). This was because, if these sums of money had 
been invested domestically they could have played a positive role in fuelling economic development and reducing unemployment in Africa (Kipyegon, 2004).

There is no commonly accepted definition of Capital flight. Capital flight is complex phenomenon that is difficult to define (Olawale and Ifedayo, 2015). Due to this, there is no theoretical standard measure of the phenomenon leading to different methods of its computation and consequently to divergent estimates (Hermes, Lensink and Murinde, 2002). The study adopted the definition of capital flight by Epstein (2005) who defined capital flight as the transfer of assets overseas to lessen the loss of principal, loss of return, or loss of control over one's economic wealth due to government-sanctioned activities. Developing countries endure huge amount of capital flight and are mostly affected (Liew, 2016). Kar and Spanjers (2015) reported that approx. US\$ one trillion in capital flight was transferred out of developing states in 2012. This was 10 times the sum of Overseas Development Aid (ODA) received that year. It was also four times higher than the US $\$ 40-60$ billion required every year to meet the Sustainable Development Goals (SDGs) by 2030 (Waris and Fröberg, 2011).

Capital flight from Africa has been denoted as an illustration of the Lucas paradox (Lucas,1990) (Ndikumana and Sarr, 2016). Ndikumana and Boyce (2018) gave evidence that African countries lost more through capital flight than they received in the form of aid or foreign private investment (net creditor). When capital flight is scaled as a proportion of GDP, Sub-Sahara Africa(SSA) topped the list, with capital flight averaging $6.1 \%$ of the region's GDP. In 2015, the East African Community had capital flight stocks of USD 124.6 billion, of which Uganda accounted for USD 23.3 billion, Kenya USD 29.4 billion, Tanzania USD 41.2 billion, Burundi USD 5.8 billion and Rwanda USD 24.9 billion on average. Expressed as ratio to GDP, capital flight was $30 \%$ in Kenya, $63 \%$ in Tanzania, $83.7 \%$ in Uganda, $213.7 \%$ in Rwanda and 181.8\% (Ndikumana and Boyce,2018). Between the year 2003 and 2012 cumulative capital flight from Kenya was US\$860 million (Kar and Spanjers, 2014). Ironically, over the same period, the net ODA received amounted to US\$1106 million (Republic of Kenya, 2013). In 2015, Ndikumana and Boyce (2018) reported that capital flight in Kenya was 30\% of the GDP.

Using portfolio choice theory, Collier et al. (2004) suggested that FDI would affect capital flight to the degree that it affected either the risks or the returns on private domestic assets. This study intended to contribute to the empirical literature by bringing in Foreign Direct Investments (FDI) as an important macroeconomic factor and examined its relationship with capital flight in Kenya. The study attempted to address the following question; Has FDI in the Kenyan economy increased the amount of capital flight? The study added to the other studies that attempted to understand capital flight and FDI from Africa. These included those by Gbadebo and Nuhu (2014); Kant (1996) and Ndikumana and Sarr (2016). To avoid variable omission bias, the study controlled for GDP growth rate and inflation rate. The study employed ARDL (Autoregressive Distributed Lag Model) procedure to analyse the data and answer the research question. The intention of choosing ARDL was because it was more appropriate for the sample due to small number of observations and mix of I (0) and I (1) variables in the sample. The ARDL results showed that FDI and lag of capital flight affected capital flight in Kenya significantly. On the other hand, GDP growth rate and inflation rate had no significant effect on capital flight in Kenya.

Kenya is on the top 20 list of African states with capital flight (Hope, 2014). Ndikumana and Boyce (2018) reported the capital flight in Kenya for the year 2015 was the capital flight was $30 \%$ of GDP. Capital flight has negative impact on economic growth, macroeconomic stability, 
income distribution and welfare and undermines the effectiveness of poverty reduction policies (Moulemvo, 2016; Nkurunziza, 2012, 2015). Fighting capital flight is, therefore, an important driver of development for poor countries like Kenya whose GDP growth rate has been deteriorating since the 1970s (Kimenyi, Mwega and Ndung'u, 2016).

Despite the serious capital flight problem in Kenya, few country-specific studies have investigated capital flight. The few that exist include (Ng'eno, 2000); Kipyegon (2004); Moeva (2007), Mudida (2011); Letete (2015); Muchai and Muchai (2016); Gachoki and Nyang'oro (2016); Letete and Sarr (2017) and recently Barasa (2018). They have examined portfolio diversification motives, political and macroeconomic uncertainty, fiscal deficits, and devaluation of local currencies as some of the factors causing capital flight. None of these studies has examined how FDI influences capital flight in Kenya. This study contributes to the literature on capital flight from Kenya by filling this gap by bringing in FDI as one of the variables in the study. The objective of the study was to determine the relationships between FDI, GDP growth rate, inflation rate and capital flight.

\section{Literature Reviews}

\section{Portfolio Choice Hypothesis}

The portfolio approach was initially established in the late 1930s (Williams, 1938; Iversen, 1935 and Tobin, 1958) and rematerialized late 1960s. In 1952, Harry M. Markowitz expounded the theory when he published a landmark paper on portfolio selection and efficient diversification of investments. The theory is built on two key assumptions that seek to explain the portfolio selection problem. Investors are assumed to prefer higher levels of final returns to lower level of final returns (Sharpe, Alexander and Bailey, 2003) and investors are very riskaverse and therefore will choose a portfolio with smallest standard deviation, where their chance of losing in a portfolio is reduced (Sharpe et. al., 2003). The theory postulates that capital flight happens due to agent needs to optimize yields on capital for an assumed level of risk (Collier et al., 2001 and Forson, Obeng, and Brafu-Insaidoo, 2017).

According to the theory, if a currency depreciation is expected, domestic wealth owners will shift their wealth out of domestic assets holdings into foreign assets holdings (Letete, 2015, Khan and Ajayi, 2000; Khan and Haque, 1985; Alesina and Tabellini, 1989). Similarly, high inflation rates, which sometimes result from fiscal deficit financing through seignorage, will lead to capital flight. Under the circumstances of high inflation pressures, domestic agents engage in capital flight to avoid erosion of the value of their monetary balances by inflation. Using portfolio choice theory, Collier et al. (2004) suggested that FDI would affect capital flight to the degree that it affects either the risks or the returns on private domestic assets. The most extensively accepted connection from FDI to capital flight is via corruption. The hypothesis rests on two steps: FDI increases corruption, and corruptly attained assets are more probable to be placed abroad (Collier et al., 2004).

\section{Herd Mentality Theory}

The theory of herding was initially developed by sociologists following the important work of French social scientist Gustave Le Bon in 1895 and some years later by George Simmel in 1903. Its origins in social psychology refer to the natural tendency to act like the others (Fiol and O'Connor, 2003). Herding happens when individuals mimic others, disregarding their substantive private information (Scharfstein and Stein, 1990). García and Ferruz (2015) identify herding as when investors choose to imitate the decisions of other members in the market or market movements. The basic assumption in the theory of herd behaviour is 
individual's rationalism that is sculpted by Bayes' theorem (Tuominen, 2017). Another vital assumption is that the choices made are made in order and that individuals are aware of the decisions made by predecessors such that there is a sequence of periods. The Bayes' theorem is what makes the herd behaviour theory possible and it is the most important assumption in this theory (Tuominen, 2017). According to Cardiff (2017) herd mentality theory views capital flight as just a matter of something happening - may be a huge economic event in the country, like a tremor - and people placing a name on that marvel, "capital flight." It echoes as if the money itself is essentially leaving when in datum the investors are intentionally putting their money into non-domestic interests (Cardiff, 2017).

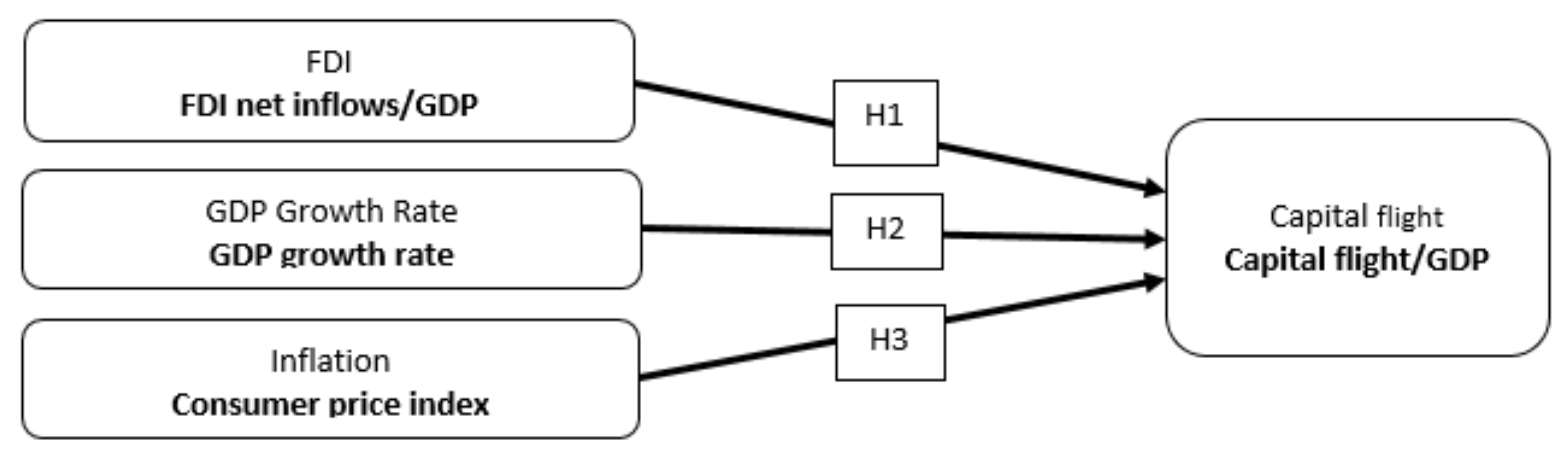

Figure 1. Conceptual Framework

The study tested the following hypotheses

1. There is no positive significant relationship between FDI and capital flight.

2. There is no significant relationship between GDP growth rate and capital flight.

3. There is no positive significant relationship between inflation and capital flight.

\section{Relationship between Foreign Direct Investment and Capital Flight}

Uddin, Yousuf and Islam (2017) examined the factors that caused capital flight from Bangladesh for the period 1993 to 2013. The findings of the study were that FDI and capital flight had a positive and significant relationship. Ndikuduma and Sarr (2016) conducted an econometric analysis based in 32 African countries for the period 1970-2013. The findings were that a positive relationship existed between the stock of FDI and capital flight. Puah et al. (2016) examined capital flight in Malaysia. The results of ARDL tests showed that FDI and capital flight had a negative relationship. Wujung and Mbella (2016) measured the association between capital flight and economic development in the Cameroon economy through the period 1970-2013. The findings were that FDI had a significant negative relationship with capital fight.

\section{Relationship between GDP Growth Rate and Capital Flight}

Salandy and Henry (2018) examined capital flight in Trinidad and Tobago during the pre and post-financial liberalization. The results indicated GDP growth and capital flight had a positive and significant relationship. Forson et al. (2017) investigated capital flight in Ghana using the ARDL estimation technique. The results showed that capital flight and GDP growth rate had long run and short-run negative relationship. Uddin, Yousuf and Islam (2017) examined the factors that caused capital flight from Bangladesh for the period 1993 to 2013. The findings were that GDP had an insignificant relationship with capital flight in two of the models. Pradhan and Gourishankar (2017) examined the causes of capital flight in India for the period 1990 to 2012. The empirical results suggested that capital flight and GDP growth rate had a positive and significant relationship. Al-basheer et al. (2016) estimated the limitations of 
capital flight during the period from 2000 to 2013 in Jordan. The statistical scrutiny showed a negative statistical significant association between the growth rate of the economy and capital flight. Cheung et al. (2016) examined China's capital flight. The empirical findings were that capital flight was not influenced by GDP growth rate.

\section{Relationship between Inflation Rate and Capital Flight}

In the face of soaring inflation, those who hold domestic assets react to the erosion of the value of their wealth by investing. According to portfolio choice theory, high and variable inflation may encourage capital flight as investor's arbitrage amongst domestic and foreign assets (Fischer,1993). The inflation rate is expected to reduce expected future returns, and therefore must be positively related to capital flight (Letete, 2015). Ahmad and Sahto (2016) explored the association amidst capital flight in Pakistan and its determinants for the period 1971 to 2011. The study demonstrated that there existed a positive relationship between capital flight and inflation in the long run whereas no relationship was found in the short run.

Cheung et al. (2016) examined capital flight in China. The empirical results indicated that capital flight was influenced by inflation rate. Muchai and Muchai (2016) sought to provide fiscal proof of capital flight in Kenya for the period 1970-2010. The results established that inflation had negative but insignificant effects on capital flight. Henry (2013) examined capital flight in Nigeria for the period 1980-2011. The results found capital flight to be mainly caused by high inflation. Maski and Wahyudi (2012) studied capital flight and its impact on economic growth in Indonesia. The results showed that inflation had no significant influence on the occurrence of capital flight in Indonesia.

\section{Research Methods}

The study adopted positivistic philosophy approach and was guided by mixed-methods sequential explanatory design. Analysis of quantitative data offered an overall understanding of the research problem (Tashakkori and Teddlie 1998; Creswell 2003). Secondary data collection sheet was used to collect quarterly time series data for calculation of capital flight and GDP growth rate, inflation and FDI from the CBK and KNBS. Secondary quarterly time series data were analyzed using STATA 13. Tests carried out before fitting the models included tests for Multicollinearity, Optimal number of lags and stationarity. Upon estimation of ARDL model, post estimation diagnostic tests were carried out to determine the fitness of the models fitted. They included; Model fitness test, Multicollinearity, Heteroscedasticity, Autocorrelation Test and Test for cointegration - Bound test. The study used quarterly time series data for the period Q1 1998- Q1 2018 obtained from the Central Bank of Kenya and KNBS. The study used an estimation technique developed by the World Bank- residual method to generate data for capital flight as follow (World Bank, 1985):

$$
K F_{i}=\left(\Delta D B_{i t}+N F D_{i t}\right)-\left(C A_{i t}+\Delta F R_{i t}\right)
$$

Where:

KF : capital flight,

$\triangle \mathrm{DB}$ : change in total debt outstanding,

NFDI : foreign direct investment,

CA : current account balance,

$\triangle \mathrm{FR} \quad$ : change in foreign reserve.

The study examined the relationship between FDI the independent variable; inflation and GDP growth rate which were the control variables and capital flight in Kenya. The specification of 
the capital flight econometric model was supported by the studies conducted by Geda and Yimer (2016), Forson et al. (2017), Hasnul and Masih (2016), Alam and Quazi (2004), Gusarova (2009), and Liew et al. (2010). The final econometric model of capital flight, therefore, was presented below:

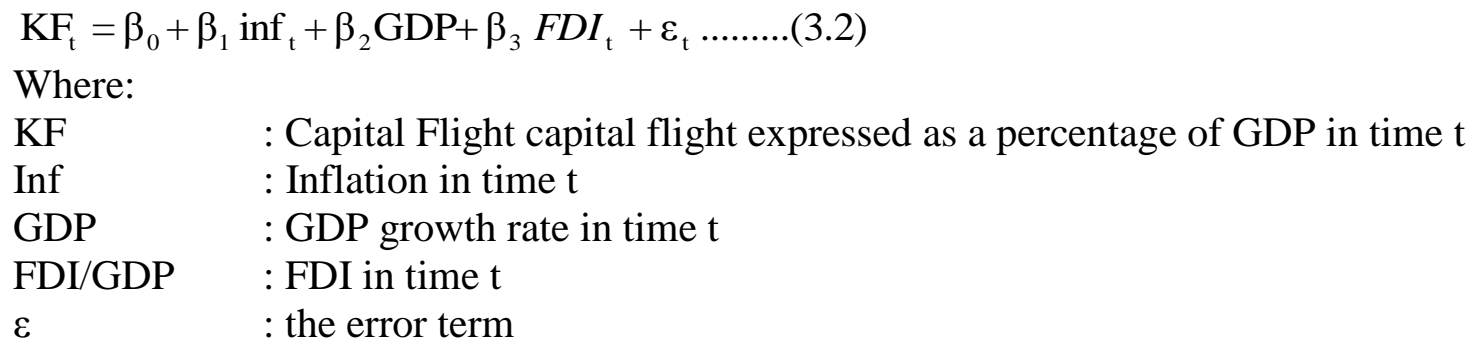

Whereas $\beta_{0}, \beta_{1} \beta_{2} \beta_{3}$ and are partial regression coefficients of independent variables which can through their signs, determine the direction of the relationship between the independent variable and the dependent variable.

\section{Results}

\section{Descriptive Statistics of Variables}

Table 1. gives the descriptive statistics of the variables. Capital flight for the period under review ranged between -0.9874 to 0.3627 with an average value of -0.4147 and a standard deviation of 0.3073 . The quarterly FDI net inflows from 0.05 percent to 7.0299 percent with a mean value of 2.1174 percent and a standard deviation of 2.0198. GDP growth rate ranged between -2.500 percent to 8.30 percent with a mean value of 4.4160 and a standard deviation of 2.2327. The inflation rate for the period ranged between 2.63 percent and 19.19 percent with a mean value of 8.0154 and a standard deviation of 4.1410 .

Table 1. Descriptive Statistics of variables: 1998-2018

\begin{tabular}{lcccc}
\hline & Capital Flight & FDI net inflows /GDP & GDP growth rate & Inflation \\
\hline Mean & -0.4147 & 2.1174 & 4.416 & 8.0154 \\
N & 81 & 81 & 81 & 81 \\
Std. dev & 0.3073 & 2.0198 & 2.2327 & 4.141 \\
Min & -0.9874 & 0.05 & -2.5 & 2.63 \\
Max & 0.3627 & 7.0299 & 8.3 & 19.19 \\
Skewness & 0.7344 & 1.1095 & -0.8745 & 1.2431 \\
Kurtosis & 3.0742 & 2.9677 & 3.5063 & 3.4818 \\
\hline
\end{tabular}

The normality and the distribution of the variables analysis results were also presented in Table 1. They revealed that capital flight was normally distributed with a kurtosis value of 3.0742 , FDI/GDP was normally distributed with a kurtosis value of 2.9677, GDP growth rate was also normally distributed because the kurtosis value was 3.506. From statistics, the kurtosis value of a normally distributed variable is always equal to 3.0. Capital flight, FDI and inflation were positively skewed meaning that majority of their observations lay on the right of the average value. GDP growth rate was however skewed to the left implying that majority of the observations lay to the left side of the average value. The conclusion made regarding the distribution of the variables as measured by the skewness and kurtosis values was supported by figure 2 . 
IJBE: Integrated Journal of Business and Economics e-ISSN: 2549-3280
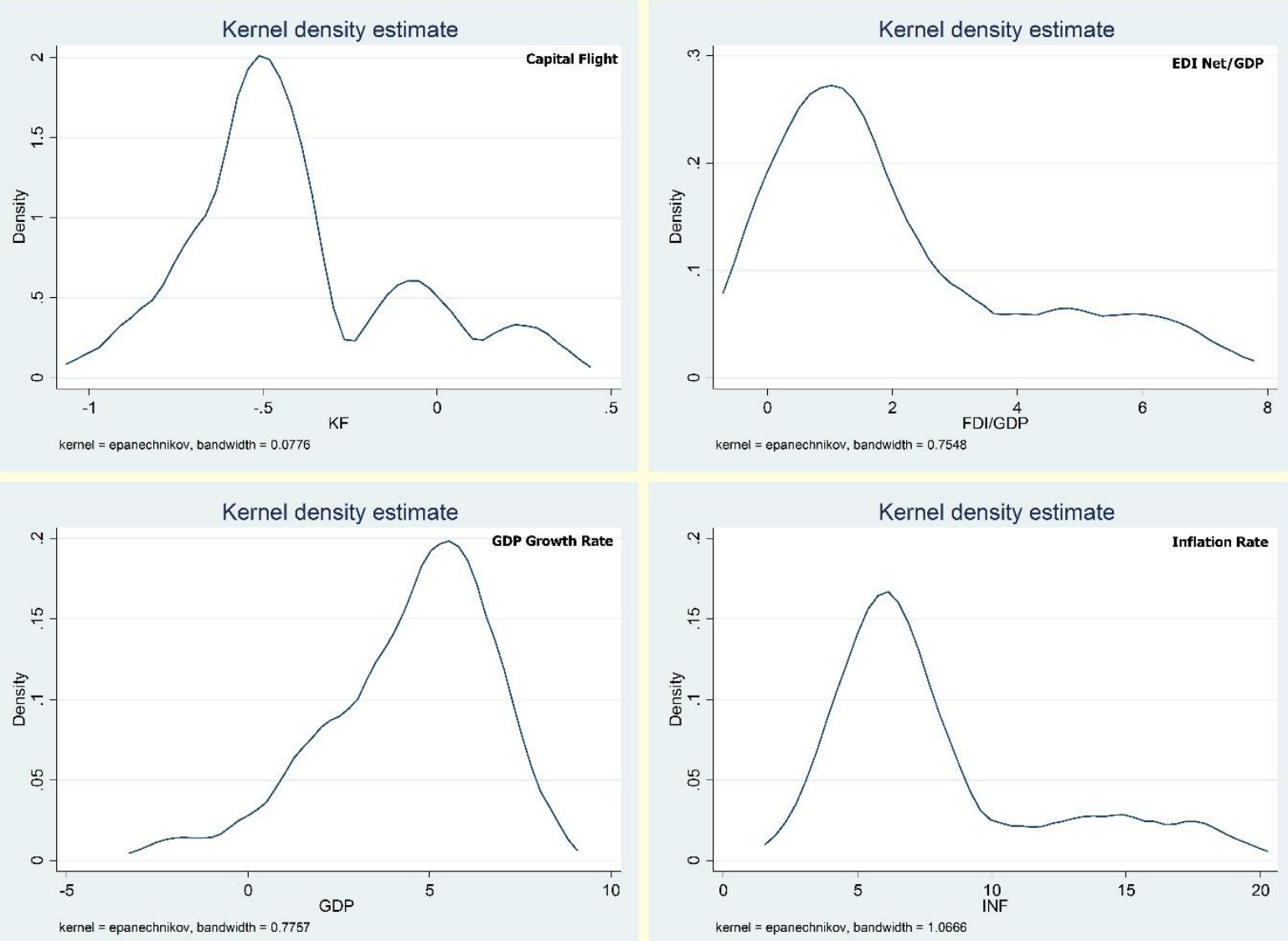

Figure 2. Density Estimation

\section{Trend Analysis of Variables}

Figure 3 showed the trend analysis of the variables over the period Q-1 1998 to Q-1 2018.

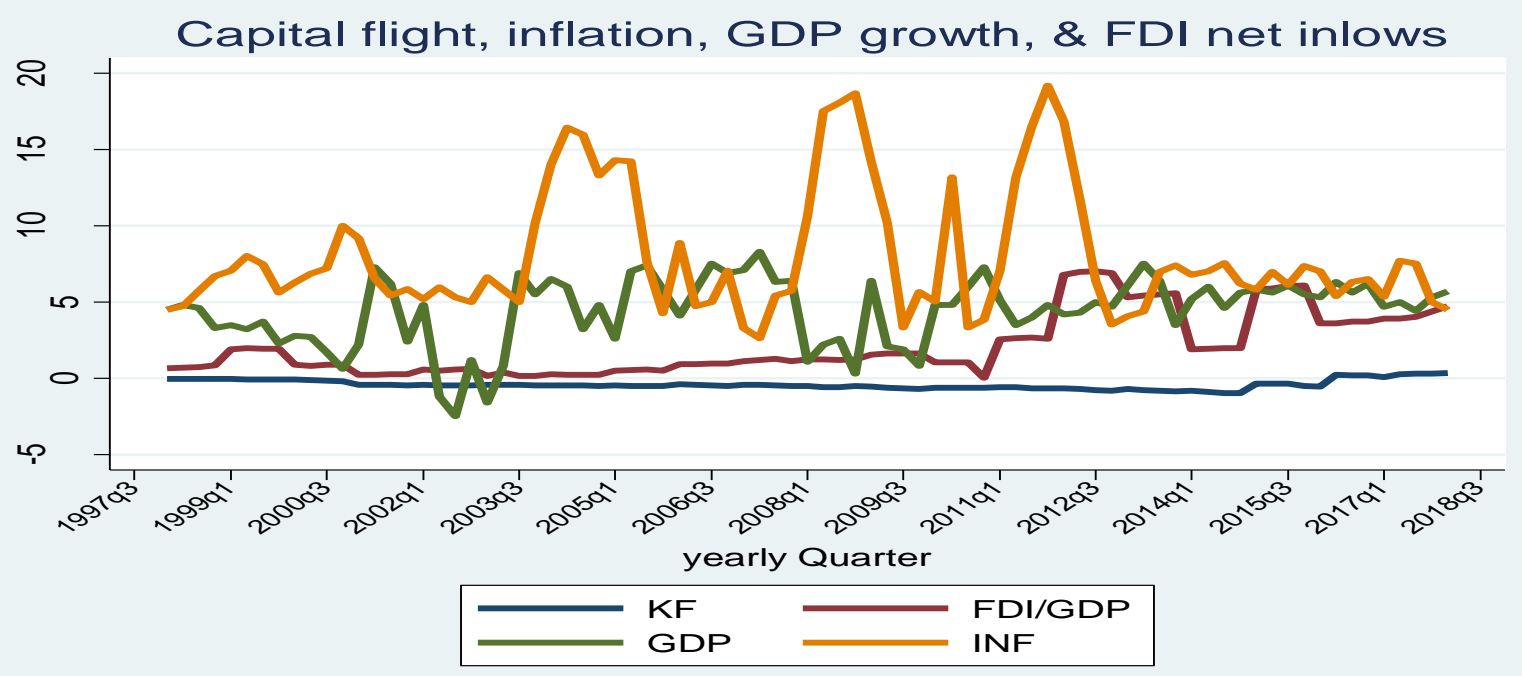

Figure 3. Trend analysis of variables: 1988-2018

Table 2 showed the levels of capital flight in Kenya over the same period. 
IJBE: Integrated Journal of Business and Economics e-ISSN: 2549-3280

Table 2. Capital flight in Kenya 1998-2018

\begin{tabular}{|c|c|c|c|c|c|}
\hline Year & Kshs Billions & Year & Kshs Billions & Year & Kshs Billions \\
\hline 1998 & - $183,183,427.15$ & 2005 & - 2,383,779,548.24 & 2012 & $-6,965,421,091.52$ \\
\hline 1999 & - $\quad 247,636,027.23$ & 2006 & - 3,205,953,486.37 & 2013 & - 7,700,015,579.96 \\
\hline 2000 & - $\quad 587,528,893.18$ & 2007 & - 4,073,416,279.34 & 2014 & - 9,250,364,167.98 \\
\hline 2001 & - 1,461,847,201.35 & 2008 & - 4,472,811,899.14 & 2015 & - 4,877,943,247.65 \\
\hline 2002 & - 1,515,040,940.10 & 2009 & - 5,057,659,357.81 & 2016 & $1,857,007,141.48$ \\
\hline 2003 & - 1,777,441,901.22 & 2010 & $-4,868,731,345.73$ & 2017 & $3,527,111,441.42$ \\
\hline 2004 & - 2,046,931,341.89 & 2011 & $-5,384,626,830.06$ & 2018 & $4,426,982,562.92$ \\
\hline
\end{tabular}

Tests for Multicollinearity

From the correlation matrix results, there existed no significant correlation between any of the variables given that no correlation coefficient was more than 0.8 for it to qualify to be a strong correlation (Green, 2012). From the results, all the variables other than GDP growth rate were positively correlated to the capital flight (Table 3).

Table 3 Correlation coefficients between variables

\begin{tabular}{ccccc}
\hline & Capital Flight & Exchange Rate & Inflation & FDI/GDP \\
\hline Capital Flight & 1.000 & & & \\
Exchange Rate & $0.3188^{* * *}$ & 1.000 & & \\
& -0.0037 & & & \\
Inflation & -0.1993 & $-0.0818^{*}$ & 1.000 & \\
& -0.0745 & 0.4677 & & \\
FDI/GDP & -0.0134 & $0.6576^{* * *}$ & -0.0795 & \multirow{2}{*}{1.000} \\
& -0.9052 & 0 & -0.4807 & \\
\hline
\end{tabular}

Note the $\mathrm{p}-$ value for all the test statistics are in parenthesis

Note: $* * *, * *, *$ denote significance level at $1 \%$, and $5 \% \& 10 \%$ respectively

\section{Tests for Stationarity of Data}

Unit root tests were conducted to determine the order of integration of the variables before the empirical model estimations. This is because estimation of the empirical model without prior knowledge on the order of integration of the variables would lead to spurious regression results. Both the Augmented Dickey-Fuller (ADF) tests and the Phillip - Peron were applied in testing the presence or the absence of unit root in each series. The results in table 4 revealed the order of integration for all variables.

Table 4. Order of integration for variable

\begin{tabular}{cccc}
\hline Variable & At level & At first difference & Order of Integration \\
\hline GDP Growth Rate & Stationary & - & $\mathrm{I}(0)$ \\
Inflation rate & Non - stationary & Stationary & $\mathrm{I}(1)$ \\
Exchange rate & Non - stationary & Stationary & $\mathrm{I}(1)$ \\
FDI/GDP & Non - stationary & Stationary & $\mathrm{I}(1)$ \\
Capital Flight & Non - stationary & Stationary & $\mathrm{I}(1)$ \\
\hline
\end{tabular}

\section{Optimal Number of Lags}

The optimal number of lags was determined to establish the number of lags that ought to be applied when running the ARDL model. Green (2012) asserted that the lag length selection test could be based on various criteria such as the Schwarz' Bayesian Information Criterion (SBIC), Hannan-Quinn Information Criterion (HQIC), Final Prediction Error (FPE) and Akaike 
Information Criterion (AIC). The overall results as presented in Table 5 revealed that the optimal number of lags for all variables was one, which was significant at $1 \%$ significance level as evidenced by the respective p-value.

Table 5. Determination of the maximum number of lags for model variables

\begin{tabular}{ccccccccc}
\hline \multicolumn{8}{c}{ Selection-order criteria } \\
Lag & LL & LR & df & p & FPE & AIC & HQIC & SBIC \\
\hline 0 & -819.56 & & & & 22917.6 & 21.39 & 21.44 & 21.53 \\
1 & -617.52 & $404.08^{*}$ & 16 & 0 & $182.77^{*}$ & $16.56^{*}$ & $16.80^{*}$ & $17.17^{*}$ \\
2 & -606.32 & 22.41 & 16 & 0.13 & 207.74 & 16.68 & 17.12 & 17.78 \\
3 & -596.81 & 19.01 & 16 & 0.27 & 248.10 & 16.85 & 17.48 & 18.44 \\
4 & -590.06 & 13.50 & 16 & 0.64 & 320.72 & 17.10 & 17.92 & 19.16 \\
\hline
\end{tabular}

\section{Overall Results of the Model}

Table 6 gave the overall results of the model. The effect of FDI was significant in influencing capital flight at $1 \%$ and $5 \%$ level of significance. This was evidenced by the respective probability values which were 0.008 and 0.015 . For the other two control variables, their effect on capital flight was insignificant at all levels of significance levels (1, 5 and 10 percent). However previous quarters' capital flight significantly affected current quarters capital flight. One percent increase in the previous quarters capital flight increased current capital flight by 0.933 ceteris peribus. From the coefficient of determination $\mathrm{R}$ - square, results indicated that 83.69 percent of all changes in the current quarter's capital flight was determined by previous quarter's capital flight, current quarter's and previous quarter's FDI net inflows, exchange rate and inflation. Only 16.31 percent of the total changes in the current quarter's capital flight was determined by the variables outside the model.

Table 6. Overall ARDL Model results

\begin{tabular}{lllllll}
\hline \multicolumn{2}{l}{$\begin{array}{l}\text { Sample: 1998q2-2018q1 } \\
\text { Number of obs =80 }\end{array}$} & \multicolumn{5}{c}{ R-squared $=0.8513$} \\
& Coef. & Std. Err. & $\mathrm{t}$ & $\mathrm{P}>\mathrm{t}$ & $95 \%$ Conf. & Interval \\
\hline Capital flight L1. & 0.933 & 0.048 & 19.4 & $0.000^{* * *}$ & 0.837 & 1.029 \\
GDP growth & 0.006 & 0.008 & 0.81 & 0.422 & -0.009 & 0.022 \\
GDP growth L1. & -0.004 & 0.008 & -0.47 & 0.638 & -0.019 & 0.012 \\
Inflation & -0.001 & 0.005 & -0.2 & & -0.012 & 0.009 \\
Inflation L1. & -0.005 & 0.005 & -0.91 & 0.363 & -0.015 & 0.006 \\
FDIGDP & 0.044 & 0.016 & 2.71 & $0.008^{* * *}$ & 0.012 & 0.076 \\
FDIGDP L1. & -0.04 & 0.016 & -2.49 & $0.015^{* *}$ & -0.073 & -0.008 \\
cons & 0.003 & 0.051 & 0.06 & 0.955 & -0.099 & 0.105 \\
\hline
\end{tabular}

Note: $* * *, * *, *$ denote significance level at $1 \%$, and $5 \% \& 10 \%$ respectively

\section{ARDL Model with Long Run and Short Run Models}

The overall model was decomposed into the long run and short-run models to determine the relationship between capital flight and the variables. Table 7 gave the results which indicated that capital flight did not have long-run relationship with the variables. The short-run model upheld the results for the previous overall ARDL. 
IJBE: Integrated Journal of Business and Economics e-ISSN: 2549-3280

Table 7. ARDL Model with Long Run and Short Run Models

\begin{tabular}{lcccccc}
\hline & Coef. & Std. Err. & $\mathrm{t}$ & $\mathrm{P}>\mathrm{t}$ & [95\% Conf. & Interval] \\
\hline $\begin{array}{l}\text { Adj } \\
\text { Capital Flight }\end{array}$ & & & & & & \\
$\begin{array}{l}\text { L1. } \\
\text { Long Run }\end{array}$ & -0.067 & 0.048 & -1.39 & 0.169 & -0.163 & 0.029 \\
GDP Growth & 0.038 & 0.118 & 0.32 & 0.749 & -0.197 & 0.272 \\
Inflation & -0.088 & 0.076 & -1.15 & 0.253 & -0.24 & 0.064 \\
FDIGDP & 0.054 & 0.12 & 0.45 & 0.654 & -0.184 & 0.292 \\
Short Run & & & & & & \\
GDP Growth & 0.004 & 0.008 & 0.47 & 0.638 & -0.012 & 0.019 \\
Inflation & 0.005 & 0.005 & 0.91 & 0.363 & -0.006 & 0.015 \\
FDIGDP & 0.04 & 0.016 & 2.49 & $0.015 * *$ & 0.008 & 0.073 \\
cons & 0.003 & 0.051 & 0.06 & 0.955 & -0.099 & 0.105 \\
\hline Not: & & & & & & \\
\hline
\end{tabular}

Note: $* * *, * *, *$ denote significance level at $1 \%$, and $5 \% \& 10 \%$ respectively

\section{Correlation Analysis between FDI on Capital Flight}

The correlation analysis results for FDI/GDP on capital flight indicated a Spearman's correlation coefficient of -0.1493 with a P-value of 0.1834 . This suggested that FDI /GDP and capital flight had a negative and statistically insignificant relationship since the P-value was not less 0.05 .

\section{Relationship between FDI /GDP on Capital flight}

The regression analysis results were extracted from the ADRL models and showed coefficients of 0.044 for current quarters FDI/GDP, -0.040 for previous quarter FDI /GDP and 0.054 for the long-run relationship (Table 8). The $\mathrm{p}$ values were 0.008 and 0.015 for current quarters FDI/GDP and previous quarters FDI/GDP respectively denoting a significant relationship at 1 $\%$ and 5\% level of significance respectively. The p-value for FDI/GDP, in the long run, was 0.654 meaning capital flight had a positive insignificant relationship with FDI/GDP in the long run. On the other hand, capital flight and current quarters FDI/GDP and previous quarters FDI/GDP had a positive and negative significant relationship respectively. The results meant that a one $\%$ increase in the current quarters FDI/GDP would lead to a $0.044 \%$ increase in capital flight and a one \% increase in previous quarters FDI/GDP would lead to a $0.040 \%$ decrease in capital flight.

Table 8. Regression results: FDI and Capital Flight

\begin{tabular}{lcccccc}
\hline Short-run & Coef. & Std errors & t-statistic & $\mathrm{P}>\mathrm{t}$ & \multicolumn{2}{c}{$95 \%$ Conf. Int } \\
\hline FDI/GDP & 0.044 & 0.016 & 2.71 & $0.008^{* * *}$ & 0.01 & 0.076 \\
FDI/ GDP (-1) & -0.04 & 0.016 & -2.49 & $0.015^{* *}$ & -0.07 & -0.008 \\
Long run & & & & & & \\
FDI / GDP & 0.054 & 0.12 & 0.45 & 0.654 & -0.18 & 0.292 \\
\hline
\end{tabular}

Note: $* * *, * *$, denote significance level at $1 \%$, and $5 \%$ respectively

\section{Hypothesis Testing}

The null hypothesis would be rejected if the $\mathrm{p}$ values were less than or equal to $0.1,0.05$ or 0.01 . The $\mathrm{p}$ values were 0.008 for current quarters FDI/GDP, 0.015 and for previous quarters FDI/GDP. The $\mathrm{p}$ values were less than 0.05 . The null hypothesis was rejected and the alternative hypothesis adopted. The p-value for FDI/GDP, in the long run, was 0.654 which is not less than 0.05 . The null hypothesis was not rejected. In conclusion, capital flight had a significant positive association with current quarters FDI/GDP, negative and significant 
relationship with previous quarters while on the other hand capital flight had a negative but insignificant relationship with FDI /GDP in the long run.

\section{Correlation between GDP Growth Rate and Capital Flight}

The correlation analysis results for GDP growth rate and capital flight indicated a Spearman's correlation coefficient of -0.0575 with a P-value of 0.6104 . This denoted that, GDP growth rate and capital flight had a negative but insignificant relationship since the P-value was not less 0.05 .

\section{Relationship between GDP Growth Rate and Capital Flight}

The regression analysis results were extracted from the ADRL models and showed coefficient of 0.006 for current quarters GDP growth rate, -0.004 for previous quarter GDP growth rate and 0.038 for quarterly GDP growth rate in the long run (Table 9). This indicated that capital flight and current quarters GDP growth rate and GDP growth rate, in the long run, had a positive relationship while previous quarters GDP and capital flight had a negative relationship. The $\mathrm{p}$ values were $0.422,0.638$ and 0.749 for current quarters GDP growth rate, previous quarter GDP growth rate in the long run respectively meaning that quarterly GDP growth rate and capital flight had an insignificant association both in the short run and in the long run.

Table 9. Regression Results: GDP Growth Rate and Capital Flight

\begin{tabular}{lcccccc}
\hline Short-run & Coef & Std errors & t-statistic & P>t & \multicolumn{2}{c}{$95 \%$ Conf. Int } \\
\hline GDP & 0.006 & 0.008 & 0.810 & 0.4 & -0.009 & 0.022 \\
GDP (-1) & -0.004 & 0.008 & -0.470 & 0.6 & -0.019 & 0.012 \\
Long Run & & & & & & \\
GDP & 0.038 & 0.118 & 0.320 & 0.7 & -0.197 & 0.272 \\
\hline
\end{tabular}

Note: $* * *, * *$, denote significance level at $1 \%$, and $5 \%$ respectively

\section{Hypothesis Testing}

The null hypothesis would be rejected if the p-value were less than or equal to $0.1,0.05$ or 0.01 . The $\mathrm{p}$ values were 0.422 , for current quarters GDP growth, 0.638 , for previous quarters GDP growth rate and 0.749 GDP growth rate in the long run. The $p$ values are not less than 0.1 . The null hypothesis was, therefore, not rejected. In conclusion, quarterly GDP growth rate and capital flight had an insignificant association both in the short run and in the long run.

\section{Correlation Analysis between Inflation Rate and Capital Flight}

The correlation analysis results for inflation rate and capital flight indicated a Spearman's correlation coefficient of -0.1854 with a $\mathrm{P}$-value of 0.0975 . This suggested that inflation rate and capital flight had a negative and significant relationship since the P-value was less than 0.1 (10\% level of significance).

\section{Relationship between Inflation Rates and Capital Flight}

The regression analysis results extracted from the ADRL models showed the relationship between inflation rate and capital flight (Table 10). The coefficients were -0.001 for current quarter's inflation rate, -0.005 , for previous quarter inflation rate and -0.088 for long-run relationship. This denoted a negative relationship meaning that when inflation rate increases capital flight decreases. The $p$ values were $0.844,0.363$ and 0.253 for current quarter's inflation rate, previous quarter's inflation rate and in the inflation rate in the long run respectively. This indicated that inflation and capital flight had a statistically insignificant negative relationship in the short run and the long run. 
IJBE: Integrated Journal of Business and Economics e-ISSN: 2549-3280

Table 10. Regression results: Inflation Rate on Capital Flight

\begin{tabular}{lcccccc}
\hline Short-run & Coef. & Std Errors & t-statistic & P>t & \multicolumn{2}{c}{ 95\% Conf. Int } \\
\hline Inflation & -0.001 & 0.005 & -0.200 & 0.844 & -0.012 & 0.009 \\
Inflation (-1) & -0.005 & 0.005 & -0.910 & 0.363 & -0.015 & 0.006 \\
Long run & & & & & & \\
Inflation & -0.088 & 0.076 & -1.150 & 0.253 & -0.240 & 0.064 \\
\hline
\end{tabular}

Note: $* * *, * * *$ denote significance level at $1 \%, 5 \% \& 10 \%$ and respectively

\section{Hypothesis Testing}

The null hypothesis would be rejected if the $\mathrm{p}$ values were less than or equal to $0.1,0.05$ or 0.01 . The $p$ values were 0.844 for current quarter's inflation rate and 0.363 , for previous quarter's inflation rate and 0.253 for inflation rate in the long run. The $\mathrm{p}$ values are not less than 0.05 or 0.1 , therefore the null hypothesis is not rejected and alternative hypothesis was not adopted. In conclusion, inflation had negative statistically insignificant relationship with capital flight.

\section{Relationship between Lagged Capital Flight and Capital Flight}

Table 11 showed the regression results extracted from the ADRL models. The coefficient for previous quarter's capital flight and capital flight was 0.933 . This indicated that capital flight had a positive relationship with lagged capital flight. The p-value was 0.000 , which was less than 0.01 meaning that the relationship was statistically significant. A one $\%$ increase in previous quarter's capital flight would lead to a $0.933 \%$ increase in capital flight.

Table 11. Regression results: Lagged Capital Flight on Capital Flight

\begin{tabular}{ccccccc}
\hline Short-run & Coef. & Std. Errors. & t-statistic & P>t & $95 \%$ Conf Int. \\
\hline Capital Flight 11. & 0.933 & 0.048 & 19.400 & $0.000 * * *$ & 0.837 & 1.029 \\
\hline
\end{tabular}

Note: $* * *, * *, *$ denote significance level at $1 \%, 5 \% \& 10 \%$ and respectively

\section{Discussion}

The first research objective was to determine the relationship between FDI and capital flight. The results showed that a One \% increase in current quarters FDI /GDP would lead to a $0.44 \%$ increase in capital flight and a $1 \%$ increase in previous quarters FDI/GDP would lead to a decrease of $0.040 \%$ in capital flight. The results, therefore, showed that current quarters FDI/GDP had a positive and statistically significant short-run relationship. The implication was that FDI inflows led to capital flight. On the other hand, previous quarters FDI/GDP had a negative statistically significant short-run relationship with capital flight. This suggested that increasing volume of FDI inflows helped reduce the magnitude of capital flight since investors could expect better macroeconomic performances. Portfolio Choice theory supported the findings. A higher level of FDI indicated that the country was doing well from an investment climate perspective. This meant that capital flight was declining as an investment at home offered more attractive returns as compared to investment abroad. Studies supporting the positive relationship between current quarter's FDI/GDP and capital flight included studies by Gankou et al. (2016); Ndikuduma and Sarr (2016) and Uddin, Yousuf and Islam (2017). Studies with consistent findings of the negative relationship between previous quarter's FDI/GDP and capital flight, included studies by Puah et al. (2016) and Wujung and Mbella (2016).

The second research objective was to determine the relationship between GDP growth rate and capital flight. The findings were that GDP growth rate did not affect capital flight in Kenya in 
the period of study. The findings were consistent with findings by Uddin, Yousuf and Islam (2017) and Cheung et al. (2016) but inconsistent with findings by Salandy and Henry (2018) and Pradhan and Gourishankar (2017) who reported a positive association and Forson et al. (2017) and Al-basheer et al. (2016) who found a negative association. The findings concurred with portfolio choice theory. Kenya's GDP has been relatively stable during the period under study. Investors are presumed to seek to maximize profits by allocating funds between domestic and foreign investment based on the relative risk-adjusted rate of return at home and abroad (Cerra et al., 2008). The relative return to investment is captured by the interest rate differential and the rate of economic growth.

The third objective of the study was to determine the relationship between inflation rate and capital flight. The results showed that inflation rate had an insignificant relationship with capital flight. Our findings could be explained by the fact that Kenya has not had periods of exaggerated and worrisome macroeconomic instability and the inflation rate have been within tolerable levels for economic players most of the time and therefore did not affect capital flight significantly. The findings are supported by portfolio choice theory. Inflation rate has been stable throughout study and therefore, there has been no need for investor to arbitrage amongst domestic and foreign assets. According to portfolio choice theory, high and variable inflation may encourage capital flight as investor's arbitrage amongst domestic and foreign assets (Fischer, 1993). Several studies that reported consistent findings to this study's findings included Ahmad and Sahto (2016); Muchai and Muchai (2016); Maski and Wahyudi (2012) however Cheung et al. (2016) and Henry (2013) reported a positive relationship.

\section{Conclusion and Suggestion}

\section{Conclusion}

The study sought to establish the relationship between FDI and capital flight over the period 1998 to 2018. The study controlled for GDP growth rate and inflation. Two ARDL models were run to help estimate the long run and short-run relationship between the variables. The findings were that both GDP growth rate and inflation did not have a significant relationship with capital flight. On the other had FDI and capital flight had a significant short-run relationship. The results also indicated that there was a short run relationship between lag of capital flight and current values of capital flight, which was positive and statistically significant.

\section{Suggestion}

The current quarters FDI /GDP had a positive relationship with capital flight in the short run, which was statistically significant at $5 \%$ level of significance. The study recommends that government adopt strategic management on FDI inflow transactions to avoid possible leakages of the same money going out as capital flight. On the other hand, previous quarters FDI/GDP had a negative relationship with capital flight in the short run, which was significant at $1 \%$ level of significance. The government should offer foreign investors attractive inducements and create a supportive environment for profitable investment as this would increase FDI inflows and lessen the occurrence of capital flight from.

Kenya Investment Authority should spearhead encouragement of FDI inflows by recommending various incentive such as tax benefits on foreign capital invested locally as well as enacting policies that would increase foreign participation in the capital market. The study's findings were that GDP growth rate and capital flight had an insignificant relationship. CBK should implement sound macroeconomic policies, which stimulate economic growth since, 
increase in economic growth reduces capital flight and when combined with the other variables; they have a joint effect on the level of capital flight. Results revealed that lag of capital flight and current values of capital flight had a positive and statistically significant short-run association. It would be necessary to devise policies that would prevent further capital flight and generate capital flight reversal e.g. repatriation of flight capital. The study examined the relationship between a few macroeconomic variables and capital flight. Future research may also study the relationship between capitals flight and additional macroeconomic variables, other non-macroeconomic variables, such as property rights, fiscal freedom, investment freedom or other variables.

\section{References}

1) Ahmad, B. and Sahto, Q.D. (2016). Determinants of capital flight in Pakistan. Journal of Business Studies, 11(2), 55-64.

2) Alam, M. I. and Quazi, R. M. (2003). Determinants of capital flight: An econometric case study of Bangladesh. International Review of Applied Economics, 17(1), 085-103.

3) Al-Basheer, A. B., Al-Fawwaz, T. M. and Alawneh, A. M. (2016). Economic Determinants of Capital Flight in Jordan: An Empirical Study. European Scientific Journal, 12 (4), 1857-7881.

4) Alesina, A. and Tabellini, G. (1989). External Debt, Capital Flight, and Political Risk. Journal of International Economics, 27(3/4), 199-220.

5) Barasa, T. (2018). Illicit Financial Flows in Kenya: Mapping of the Literature and Synthesis of the Evidence. www.pasgr.org/wp-content/uploads/2018/.../Kenya-Illicit-Financial-Flows-Report.pdf

6) Boyce, J. K. and Ndikumana, L. (2001). Is Africa a net creditor? New estimates of capital flight from severely indebted sub-Saharan African countries, 1970-1996. Journal of Development Studies, 38(2), 27-56.

7) Boyce, J. K. and Ndikumana, L. (2012). Capital Flight from Sub-Saharan African Countries: Updates 1970-2010. PERI Research Report. Amherst, MA. Political Economy Research Institute.

8) Cardiff, P. (2017, July 17). Which economic growth model/theory best explains capital flight? Retrieved from https://www.quora.com/Which-economic-growth-model-theory-best-explainscapital-flight.

9) Cheung, Y.W., Steinkamp, S. and Westermann, F. (2016). China's Capital Flight: Pre-and PostCrisis Experiences Journal of International Money and Finance, 66, 88-112.

10) Collier, P., Hoeffler, A. and Patillo, C. (2001). Flight Capital as a Portfolio Choice. World Bank Economic Review, 15 (1), 55-80.

11) Collier, P., Hoeffler, A. and Patillo, C. (2004). Africa's Exodus: Capital Flight and the Brain Drain as Portfolio Decisions. Journal of African Economies, 13, 15-54.

12) Epstein, G.A. (2005). Capital Flight and Capital Controls in Developing Countries. Northampton: Edward Elgar.

13) Fiol, C. M., and O'Connor, E.J (2003). Waking Up! Mindfulness in the Face of Bandwagons, Academy of Management Review, 28, 54-70.

14) Fischer, S. (1993). The Role of Macroeconomic Factors in Growth. Journal of Monetary Economics, 32, 485-512.

15) Forson, R., Obeng, K.C, and Brafu-Insaidoo, W. (2017), Determinants of Capital Flight in Ghana (2017). Journal of Business and Enterprise Development; Vol. 7, PP 151-180.

16) Gachoki, C. and Nyang 'oro, O. (2016). Impact of Capital Flight on Private Investment in Kenya. International Journal of Economics, 1 (2), 1 - 15.

17) Gankou, J. M., Bendoma, M. and Sow, M. N. (2016). The Institutional Environment and the Link between Capital Flows and Capital Flight in Cameroon. African Development Review, 28 (S1), 6587. 
18) García, M. A., and Ferruz, L. (2015). Pension Funds: Financial Econometrics on the Herding Phenomenon in Spain and the United Kingdom. En C.-F. Lee, \& J. C. Lee, Handbook of Financial Econometrics and Statistics (págs. 1801-1828). New York: Springer-Verlag.

19) Gbadebo, A. D. and Nuhu, M. (2014). The relationship between Foreign Direct Investment and Capital Flight in Nigeria. International Journal of Advanced Research in Statistics, Management and Finance, 2 (1).

20) Geda, A. and Yimer, A. (2016). Capital Flight and its Determinants: The Case of Ethiopia. African Development Review, 28 (S1), 39-49.

21) Greene, William H. (2012, Econometric Analysis, Prentice-Hall. 7th ed.

22) Gusarova, V. (2009). The impact of Capital flight on economic growth. Unpublished Master's Thesis of the KYIV School of 'Economics.

23) Hasnul, A. G. and Masih, M. (2016). Role of instability in affecting capital flight magnitude: An ARDL bounds testing approach. Paper No. 72086, M P R A, Paper No. 72086.

24) Henry, A. W. (2013). Analysis of the Effects of Capital Flight on Economic Growth: Evidence from Nigerian Economy (1980-2011). Analysis, 5(17).

25) Hermes, N., Lensink, R. and Murinde, V. (2002). Capital flight, policy uncertainty, and the instability of the international financial system. In A. Mullineux and V. Murinde, eds., Handbook of International Banking. Cheltenham: Edward Elgar (forthcoming) IMF.

26) Hope, K.R, (2014). Kenya's corruption problem: causes and consequences, Commonwealth \& Comparative Politics, 52:4, 493-512.

27) Kant, C. (1996). Foreign Direct Investment and Capital Flight. New Jersey: International Finance Section Department of Economics of Princeton University.

28) Kar, D and Spanjers, J. (2014). Illicit Financial Flows from Developing Countries: 2003-2012. Global Financial Integrity. Retrieved from www. gfintegrity. Org.

29) Kar, D. and Spanjers, J. (2015). Illicit Financial Flows from Developing Countries: 2004-2013. Global Financial Integrity. Retrieved from www. integrity. Org.

30) Kenya Economic Report. (2017). Sustaining Kenya's Economic Development by Deepening and Expanding Economic Integration in the Region, Kenya Institute for Public Policy Research and Analysis (KIPPA).

31) Khan, M. S. and Haque, N. U. (1985). Foreign Borrowing and Capital Flight: A Formal Analysis. International Monetary Fund Staff Papers, 32, 606-28.

32) Khan and Ajayi S.I (2000). External Debt and Capital Flight in sub-Saharan Africa. IMF Institute. International Monetary Fund. Washington D.C.

33) Kimenyi, S.M., Mwega, F.M and Ndung'u, S.N. (2016) African Lions: Kenya country case study: United Nations University-World Institute for Development Economics Research (UNU-WIDER), the University of Cape Town's Development Policy Research Unit (DPRU).

34) Kindleberger, C. P. (1987). A Historical Perspective. Donald R. Lessard, and John Williamson (eds.), Capital Flight and Third World Debt, Washington DC, Institute for International Economics, 7-26.

35) Kinuthia, B.K., Murshed, S.M. (2014). FDI determinants: Kenya and Malaysia compared, Journal of Policy Modelling, 37, $388-400$.

36) Kipyegon, L. (2004). Determinants of capital flight from Kenya. Unpublished masters thesis. Kenyatta University.

37) Letete, E. M. (2015). Essays on Institutions and Economic Development in Kenya: Degree of Doctor of Philosophy Thesis. University of Cape Town.

38) Letete, E. and Sarr, M. (2017). Illicit Financial Flows and Political Institutions in Kenya, Working Paper Series $N^{\circ} 275$, African Development Bank, Abidjan, Côte d'Ivoire. 
IJBE: Integrated Journal of Business and Economics e-ISSN: 2549-3280

39) Levis, M., Muradoglu, G. and Vasileva, K. (2011). Herding in FDI Outflows retrieved Fromhttps://www.cass.city.ac.uk/_data/assets/word_doc/0009/79389/Vasileva.doc

40) Liew, S.L. (2016). Review on Determinants of Capital Flight Review on Determinants of Capital Flight. MPRA. Retrieved from https://mpra.ub.uni-muenchen.de/70445/

41) Lucas, R. E. (1990). Why Doesn't Capital Flow from Rich to Poor Countries? American Economic Review, 80 (2), 92-96.

42) Maski, G., \& Wahyudi, S. T. (2012). Study on the Capital Flight and Its Impact on Economic Growth: A Case Study in Indonesia. Journal of Basic and Applied Scientific Research, 2(7), 71687174.

43) Moeva, Z. S.A. (2007). Determinants of Capital Flight in Kenya (1987-2007). Unpublished Master thesis, University of Nairobi.

44) Moulemvo, A. (2016). Impact of Capital Flight on Public Social Expenditure in Congo-Brazzaville. African Development Review, 28 (S1),113-123.

45) Mpenya, A.H.T., Metseyem, C. and Epo, B.N. (2016). Natural resources and capital flight in Cameroon. African Development Review 28(S1):88-99.

46) Muchai, D. N., and Muchai, J. (2016). Fiscal Policy and Capital Flight in Keny. African Development Review. 28( S1), 8-21.

47) Mudida, R. (2011). Empirical Aspects Of Capital Flight in Kenya, 1970-2009. Nairobi: Navarra Center for International Development Working Paper No 08/2011.

48) Ndikumana, L.and Boyce, J. K. (2003). Public debts and private assets: Explaining capital flight from Sub-Saharan African countries. World Development. 31 (1): 107-130.

49) Ndikumana, L. and Boyce, J. K. (2018). Capital Flight from Africa Updated Methodology and New Estimates. Research Report, Political Economy Research Institute, University of Massachusetts at Amherst.

50) Ndikumana, L. and Sarr, M. (2016). Capital flight and Foreign direct investment in Africa: An Investigation of the role of natural resource endowment. WIDER Working Paper 2016/58.

51) Ng'eno, N.K. (2000). Capital Flight in Kenya. in: Ajayi, I. and Khan, M. (eds). External Debt and Capital Flight in Sub-Saharan Africa. Washington, D.C.: The IMF Institute., 300- 321.

52) Nkurunziza, D. J. (2012). Illicit Financial Flows: A Constraint on Poverty Reduction in Africa. Association of Concerned Africa. Scholars Bulletin, 87, 15-21.

53) Nkurunziza, J. D. (2015). Capital Flight and Poverty Reduction in Africa, in I.

54) Ajayi and L. Ndikumana (eds.), Capital Flight from Africa: Causes, Effects and Policy Issues (pp. 81-110), Oxford University Press, Oxford.

55) Olawale, O. O. and Ifedayo, M. O. (2015). Impacts of Capital Flight on Economic Growth in Nigeria. International Journal for Innovation Education and Research.3 (8).

56) Pradhan, A.K and Gourishankar, S.H. (2017). The Capital Flight from India: A Case of Missing Woods for Trees. The Singapore Economic Review, 62, 2.

57) Puah, C.H., Liew, S.L. and Abu Mansor, S. (2016). Macroeconomic Determinants of Capital Flight: An Empirical Study in Malaysia. International Business Management, 10 (13), 2526-2534.

58) Salandy, M. and Henry, 1. (2018). Determinants of Capital Flight from Beautiful Places: The Case Of Small Open Economy Of Trinidad And Tobago, The Journal of Developing Areas, 52(4)

59) Scharfstein, David S, and Jeremy C Stein. 1990. Herd Behavior and Investment.American Economic Review 80, 465-479.

60) Sharpe, W., Alexander, G., and Bailey, J. (2003). Investments. New Delhi: Prentice-Hall of India.

61) Tashakkori, A. and Teddlie. C. (1998). Mixed methodology: Combining qualitative and quantitative approaches. Applied Social Research Methods Series, vol. 46. Thousand Oaks, CA: Sage.

62) Tobin, J. (1969). A General Equilibrium Approach to Monetary Theory. Journal of Money, Credit and Banking, 1, 15-29. 
IJBE: Integrated Journal of Business and Economics e-ISSN: 2549-3280

63) Tuominen, N. (2017). A Basic Theory of Rational Herd Behaviour and Informational Cascades Does it apply to Financial Markets? Thesis Aalto University's School of Business.

64) Uddin, M. J., Yousuf, M. and Islam, R. (2017). Capital flight affecting determinants in Bangladesh: An Econometric Estimation. International Journal of Economics, Commerce and Management 8.

65) Waris, A. and Fröberg, K. F. (2011). Bringing the billions back How Africa and Europe can end illicit capital flight. Stockholm: Forum Syd förlag.

66) Wiliams, J. (1938; 1997). The Theory of Investment Values. New York: Fraser Publishing.

67) Wujung, V. A., and Mbella, E. (2016). Capital Flight and Economic Development: The Experience of Cameroon. Economics, 5(5), 64-72. 